\title{
9
}

\section{The tradition of post-tradition}

\author{
Stephen Turner
}

\section{Introduction}

According to its Google Ngram, the term 'post-traditional' arrives at the turn of the twentieth century, but only begins to be widely used after 1960, probably as a result of its appearance in a subtitle of a book by Robert Bellah, ${ }^{1}$ after which its use has continued to increase geometrically, up to the present. There is a core problem with the term which is signalled by this citation pattern. It can be understood as a novel theoretical concept which applies to the last half of the twentieth century, telling us something about the meaning of our own time. The term, however, has a problematic relation to a much deeper, older and more pervasive set of distinctions, involving modernity and the larger trajectory of European society from the medieval period on, the Enlightenment, democratization, capitalism and industrialization, urbanism, and 'rationalization' and differentiation. It also followed, and resembled, a long-running discussion of the prospects for a new kind of society, based on a new or revised spiritual order or new values, that paralleled this discussion. Although there is a vague connection to the classical sociological literature, there is a sharp break between the 'posttraditional' literature and the 'spiritual order' and new values literature. The new literature neither engages nor cites it. Yet these literatures closely resemble one another, and share the same themes and much of the same anti-liberal, anti-individualist normative orientation.

This poses a problem for writing an intellectual history. Why was there so little textual continuity or engagement with the earlier literature in the discussion of these topics? Did they identify something genuinely novel with the term, as they claimed? Or did they unwittingly reproduce the distinctions made in the past? These turn out to be less questions of intellectual history - though there is an important historical fact that bears on them - than questions about the concept itself. Does it capture something new? The question can't be answered without getting a clear understanding of the concept itself. In what follows, I will focus on explication, and 
particularly on the problem of novelty as it appears within the texts themselves, which struggle, largely unsuccessfully, with the question of how post-traditionalism differs from modernity, which is at the core of the claim to novelty. But to see why the claim of novelty is problematic also requires some intellectual history and biography.

\section{The original problem}

It is not too much to say that characterizing the transition to modernity was the core problem of the modern social sciences, and certainly of sociology. The Enlightenment thinkers problematized tradition in contrast to reason, Burke problematized their notion of tradition, the Saint-Simonians problematized and historicized the Enlightenment thinkers themselves as products of the decay of the previous 'organic' epoch. The revisions of Saint-Simon's account, in the hands of Comte and Marx, who introduced their own periodizations, dominated early sociology and much of the social thinking of the mid nineteenth century. Their successors offered multiple versions of the distinction between the two kinds of society: Howard P. Becker's sacred and secular; Durkheim's mechanical and organic solidarities; Henry Sumner Maine's status and contract; Robert Redfield's folk and urban; Herbert Spencer's military and industrial; Tönnies' Gemeinschaft and Gesellschaft; and the one to which the users of term 'post-traditional' most typically refer, Max Weber's distinction between traditional and rational authority. These were synthesized in an influential way for professional sociology in Talcott Parsons' pattern-variables, which divided the basic tendencies of societies, which themselves clustered into modern and pre-modern.

A good baseline for understanding this literature is the account given by Herbert Spencer, the most influential source in the nineteenth century and the one to whom most of these alternative accounts were addressed. Spencer was a resolute defender of the rise of the autonomous individual, ${ }^{2}$ a notable optimist about the changes, and rejected the idea that liberalism was an interregnum. He believed that the decline of religion meant that mutual tolerance, the 'daily habit of insisting on self-claims while respecting the claims of others, which the system of contract involves', would be characteristic of 'a life carried on under voluntary co-operation' rather than the traditional 'life carried on under compulsory co-operation' ${ }^{3}$ of the past. But for many of these thinkers, the evaluation was reversed: the corrosive effects of Protestant individualism are the central fact of modernity, the product of which was political and moral individualism. At the core of the critiques on both sides - the moral regeneration and the new values sides - is nostalgia 
for the integrated and ordered societies of pre-modern Europe. Modernity, accordingly, was the destruction of this order.

This was, so to speak, a professional literature, or a proto-professional one: these texts became the core of 'classical social theory' and early sociology. But there was a public, non-professional discourse on these issues that was 'public', and was bound up with the problem of religion. This was a discussion that began with the challenge of Saint-Simon, which was taken up, loudly, in England, initially by Anglican thinkers. ${ }^{4}$ The Saint-Simonians not only looked back to the organic periods of the past, but to the organic period to come, which for them meant a completely new system of morality and, not incidentally, relations between the sexes. For them, and for many of the thinkers listed above, such as Comte, the period of liberalism was an interregnum: an unsustainable anarchy of opinions. This was an idea with special resonance in religious circles throughout the nineteenth century. Their reaction to Saint-Simonianism took two basic forms: the first was to accept it and to begin to construct a replacement religion or religious object, appropriate for the next organic period, as Comte did; the second was to reconstruct Christianity in such a way, for example as a kind of socialism, to make the new model Christianity into the replacement religion. Prominent public intellectuals such as Balfour actively engaged in this discussion in the late nineteenth century. ${ }^{5}$ And there were many variations on these ideas, and reactions to them, such as the writings of Karl Pearson, who blamed Protestantism for the ills of modernity and spent his time in Germany as a student seeking out Passion Plays (even writing one of his own, which, as Ted Porter puts it was 'also about applying lessons from the study of medieval culture to the needs of the present'), ${ }^{6}$ wished to substitute the worship of the state for religion and have scientists revered as priests. ${ }^{7}$ The fundamental options that remained after a discussion that spanned a century were the same as those with which the discussion began: spiritual regeneration or new values that would produce the solidarity and authority that older doctrines were failing to produce.

In the interwar period, this long-running discussion took a darker and more radical turn. The Great War led to disillusionment with the idea of progress. The Bishop of Ripon made a much-publicized plea to suspend science until the culture could catch up. ${ }^{8}$ And culture was trying to: new ideas about women's roles, marriage and sex were widely discussed, reaching a peak in Bertrand Russell's Marriage and Morals, ${ }^{9}$ and the response to Russell included a reaffirmation, along with a rethinking, of Christian doctrine. ${ }^{10}$ There was a parallel discussion in the United States, in terms of the idea of companionate marriage, and its model of personal development and individual satisfaction for both sexes. ${ }^{11}$ There were parallel discussions of religion as well. Charles Ellwood, in an influential book, called for the 
reconstruction of religion, a variation on the earlier themes of spiritual regeneration in a 'social' direction, going beyond the Social Gospel of the pre-war period. ${ }^{12}$ Reinhold Niebuhr provided an even more successful, but darker, alternative to this, rejecting social optimism, in such books as Moral Man and Immoral Society. ${ }^{13}$

By the time of the economic crisis of the 1930s, the British side of this literature had turned into a rich mix of nostalgia for the orderly societies of the Middle Ages combined with Christian socialism, for example in the writings and activism of R. H. Tawney, ${ }^{14}$ as well as to curiosity about the apparent successes of the Bolshevik regime and both Nazi and fascist 'planning', which contrasted both to liberal politics and liberal economics, both of which were seen as failing to meet the demands of the day. But the crisis in question was framed in moral terms. The Moral Rearmament movement, which had an international reach and agenda, was launched in 1938 in response to the spiritual crisis of the time, and explicitly conceived in response to Nazism.

The arrival of the war focused the discussion of the moral crisis. One theme was the question of what the war was being fought for: Robert Maynard Hutchins and John Dewey debated the question in the pages of Fortune..$^{15}$ The famous London discussion group The Moot debated the possibility of reviving Anglicanism or alternatively of creating a new social doctrine with the force of religion, ${ }^{16}$ in contiguity with the writings of T. S. Eliot, such as his tract Christianity and Culture. ${ }^{17}$ The Moot's participants were concerned with the biggest of pictures, the problem of how the lessons of past societies and social change could inform the creation of future societies. They tended to think of the present as an unsatisfactory interregnum between coherent orders. And they were not alone in having difficulty coming to agreement. In The Year of Our Lord 1943 Allan Jacobs shows the idea of the war as a contest of values with Nazism was widely accepted, but the many intellectuals who contributed to this discussion had trouble agreeing on what these values were. ${ }^{18}$

Then it all stopped. The end of the war meant the end of this selfsearching dialogue, and a turn to the conflicts of the Cold War and to the celebration of the victory of liberal democracy and the expanded place of Communism in the world. Tawney's Christian socialism was institutionalized into the bureaucracy of the welfare state and lost its spiritual character. ${ }^{19}$ Mannheim's ideas on planning a social order complete with planned values had the same fate. ${ }^{20}$ In Britain, the kind of non-professional public sociology that had provided a home for this kind of work was replaced by a newly professionalized British Sociological Association that lacked interest in these civilizational concerns, and disdained their predecessors. ${ }^{21}$ In the United States, a new historiography and social theory of consensus 
was created in such works as Richard Hofstader's The American Political Tradition. ${ }^{22}$ The sense of living in an interregnum evaporated, as did the urgency of the concerns of the earlier discussion.

\section{The fresh start}

Alasdair MacIntyre, Robert Bellah and Anthony Giddens are the three most prominent thinkers associated with the concept of post-traditionalism. None of them ever engaged this earlier literature, and apparently were unaware of it though much of their thinking repeats its core ideas, and ultimately came to the same options: spiritual regeneration or new solidaristic values, together with opposition to liberal values such as the ideal of the autonomous individual. Their path was, however, through a different route: Marxism, and a dissatisfaction with Marxism. The ten years between the older members of the group, born in 1928, and Giddens, born in 1938, turned out to be decisive. When the Hungarian revolution and the death of Stalin split the left, and drove many intellectuals out of the Communist party, Bellah and MacIntyre were adults for whom the party had been a primary source of identity. MacIntyre had an established reputation as a Marxist writer, writing dozens of articles for journals on the left, and had been a party member. Bellah, as a Harvard undergraduate, had been a leader of the John Reed Club and was a party member until 1949. In 1956, he was still at Harvard, refusing to testify against his former comrades. ${ }^{23}$ Both of them had a developed distaste for modern liberal society. Giddens was just eighteen, three years from graduation from Hull. But Marx was the dominant social thinker in Giddens' own academic preparation. Giddens' first book, Capitalism and Modern Social Theory, reiterated the thesis that capitalism was the fundamental structuring fact of modern society. For him, the 1960s were the break with the past that needed to be theorized in a new way: post-traditionalism supplied him with terminology to do so.

For these three thinkers the Marxist background, and their different attempts to go beyond it, were decisive for their development. MacIntyre's Marxist writings of the late 1950s reveal precisely what was at stake: the desire for a new moral order, 'an alternative to the barren opposition of moral individualism and amoral Stalinism'. ${ }^{24}$ This was a commitment he never abandoned. Liberalism was never an option: Marxism had revealed that liberalism was 'a deceiving and self-deceiving mask for certain social interests' which 'tends to dissolve traditional human ties and to impoverish social and cultural relationships'. ${ }^{25}$ Bellah shared MacIntyre's horror of moral individualism. He later cited as an early motivation his 'Ambivalence 
toward the Southern California culture in which I grew up', and 'the apparently chaotic society in which I lived' ${ }^{26} \mathrm{He}$ was to become famous for his leadership of the team that wrote the bestselling Habits of the Heart, a condemnation of American individualism. For Giddens, the problem was more academic: he came to believe that the tradition of social theory, dominated by Marx, was no longer informative and needed to be replaced. His later, political, phase, reflected his rejection of the traditions of the Labour Party; without embracing liberalism: he sought a 'third way'.

The disconnect between the literature deriving from the reaction to SaintSimon and the post-Marxist, or more precisely post-Stalinist literature, was a result of this different starting point. The former Marxists who faced an existential moral crisis after the death of Stalin and the Hungarian revolution were not searching for a new moral order to solve the problems of civilization, nor for moral regeneration as the older discussion did. They were searching for a replacement for the moral orthodoxy and vision of the future they had derived from Communism and the Soviet model. They only came to solutions to this problem that resembled the other tradition long after the moment of crisis had passed. Post-traditional, in this intellectual context, means post-bourgeois. But Marxism did not have a category for a society that was post-bourgeois in its morality and other than proletarianrevolutionary. This was the gap that the concept served to fill for them. The concept suffered from fundamental problems, most of which were the indirect result of the Marxist origin of the problematic itself. It lacked a coherent account of tradition to be 'post', and faltered in distinguishing the post-traditional from the modern, a concept that came, confusingly, to replace 'bourgeois society', and in characterizing tradition itself.

Because these three thinkers, with the partial exception of Giddens, did not proceed from a critique of their predecessors either in the protoprofessional 'modernity' tradition or the long tradition of arguing over the reinvention of the medieval social order or new values, we are left with a lacuna. Their characterizations of post-tradition use concepts that resemble the concepts in these literatures. But we do not have a developed account in their own voice of the differences between 'post-traditionalism' and this myriad of past voices. So what was novel? There seems to be a simple answer to the question. Tradition and traditional societies suppressed the 'self' in a prison of duties, ascriptive demands and restrictions, typically with religious justifications. This was never fully effaced by modernization. The concept of 'post-traditional' appears to be a radicalization in the face of such issues: it implies, in the term itself, to be about a break not only with particular traditions, which even theorists of modernity acknowledge persist into the modern world, but with tradition as such, or at least with tradition in the normal understanding of tradition. In the later incarnations of 
the concept, for example with Giddens and Scott Lash, post-traditionalism means the end of traditional social roles and the possibility - or burden - of self-invention, a change whose full force has only recently been felt. ${ }^{27}$ But how novel was this, as a concept to be applied to historical change or as a historical phenomenon itself?

We can give a brief account of this problem by starting with the thinker who provides the most complete attempt to distinguish modernity and post-traditionalism: Anthony Giddens. Writing on modernity, Giddens provides the following rough definition: 'As a first approximation, let us simply say the following: "modernity" refers to modes of social life or organization which emerged in Europe from about the seventeenth century onwards and which subsequently became more or less worldwide in their influence. ${ }^{28}$

The goal of Giddens' own analysis is to identify the features that make modernity unique as a form of social life:

The views I shall develop have their point of origin in what I have elsewhere called a 'discontinuist' interpretation of modern social development. By this I mean that modern social institutions are in some respects unique - distinct in form from all types of traditional order. Capturing the nature of the discontinuities involved, I shall argue, is a necessary preliminary to analysing what modernity actually is, as well as diagnosing its consequences for us in the present day. ${ }^{29}$

The term 'some respects' is telling. Giddens identifies multiple discontinuities: 'the sheer pace of change', the global 'scope of change'; the fact that at least some 'modern social forms are simply not found in prior historical periods - such as the political system of the nation-state, the wholesale dependence of production upon inanimate power sources, or the thoroughgoing commodification of products and wage labour ${ }^{30}$; and the fact that even sites of apparent continuity, such as cities, are ordered according to quite different principles from those which set off the pre-modern city from the countryside in prior periods.

These are largely changes external to the individual and the individual mind. In contrast, post-traditional society, or late modernity, is characterized by an internal change, the rise of a new kind of self: a reflexive self, which does not merely occupy social roles, even chosen roles, but which creates for itself, through its beliefs about the self, a new kind of self, based on 'a person's own reflexive understanding of their biography', ${ }^{31}$ a kind of therapeutic self in which a person's self-conception depends on monitoring and revising their self-understanding. This gives us a reasonably clear distinction: modernity is characterized by a mixture of traditional and novel forms; late modernity or post-traditional society is characterized by a particular novelty, the reflexive self. 
But with Bellah we can see the difficulties with this claim of novelty as a historical thesis. The notion of the self appears to be novel, but it too has a long history. Bellah, in the essay on secularization he included in the book in which the term post-traditional was introduced, employs a periodization of religious types based on the self: 'The historic religions discovered the self; the early modern religion found a doctrinal basis on which to accept the self in all its empirical ambiguity; modern religion is beginning to understand the laws of the self's own existence and so to help man take responsibility for his own fate. ${ }^{32}$ This raises the question of the dating of the reflexive self, and the modern self, and whether it is the product of an internal or an external change.

The concept of traditional societies appears in connection with the 'modernization theory' that flourished in the 1950s. Here we get a puzzling answer to this question of dating, and a different answer to the question of what is internal and what is external. 'Traditional societies' were undergoing 'development' and decolonization, driven by external changes, but also motivated by internal issues: a case of the explanation of the new based on elements of the old. As Bellah noted:

The pressures of modernization, then, do not undermine idyllic societies of happy farmers whose lives would be perfectly happy if they were only left alone. It provides the concepts to express doubts and demands that were already just below the surface of consciousness. It provides an atmosphere of hope, often unrealistic, that things will soon be better. ${ }^{33}$

This is a less than nostalgic view of traditional societies, and presents modernization as a good - a highly desired, but not unalloyed, good. And there is another side to modernization theory and the theory of 'traditional' societies that emphasizes quasi-rational resistance to change and also the quasi-rational motives for modernization such as the imitation of 'modern' forms for the purpose of prestige. These reflect the idea of a kind of self-creation based on motives that were already just below the surface of consciousness - supposedly a feature of the post-traditional, but in classically peasant societies.

Like Giddens, Bellah is concerned with the co-existence of modern and traditional elements. He presents an account of the good kind of modernization, one that tempers liberalism and individualism with modern versions of traditional collectivizing institutions that are functional substitutes for them, but which support the autonomous individual without oppressing. It is worth quoting a passage at length.

Modernization carries with it a conception of a relatively autonomous individual with a considerable capacity for adaptation to new situations and for innovation. Such an individual has a relatively high degree of self-consciousness 
and requires a family structure in which his independence and personal dignity will be recognized and where he can relate to others not so much in terms of authority and obedience as in terms of companionship and emotional participation. Such an individual also requires a society in which he feels like a full participating member, whose goals he shares and can meaningfully contribute to. Finally he requires a worldview that is open to the future, gives a positive value to amelioration of conditions in this world, and can help to make sense of the disruptions and disturbances of the historical process. ${ }^{34}$

This vision of modernization echoes Spencer with respect to the demise of priestly authority and rise of the autonomous, contract-making individual. It also provides a normative standard of feeling like a member of a society with goals and having a progressive social vision: solidaristic values. And in Bellah's later writing he uses this same image as a counterpoint to the excessive individualism he ascribes to contemporary America. ${ }^{35}$

It raises a question. The degree of autonomy allowed to what was called in the 1930s and 1940s 'the new socialist man' was a problem: the new socialist man was a man of the left, with a collective orientation, but whose orientation was a product of his maturity and autonomous choice - distinct from 'economic man', enslaved to acquisition. This 'autonomy' was always problematic, and became more so after Stalin's death, when the moral confusion noted by MacIntyre set in. The new normative standard allowed for more autonomy and recoiled from Stalinist submission. But the relatively autonomous individual of Bellah, with his new-found self-consciousness, seems indistinguishable not only from the reflexive self of Giddens but also from the optimistic autonomous self of Spencer, who, on Spencer's own account, as part of his moral development, becomes averse to harming others.

[T] he thief takes another man's property; his act is determined by certain imagined proximate pleasures of relatively simple kinds, rather than by less clearly imagined possible pains that are more remote and of relatively involved kinds. But in the conscientious man, there is an adequate restraining motive, still more re-representative in its nature, including not only ideas of punishment, and not only ideas of lost reputation and ruin, but including ideas of the claims of the person owning the property, and of the pains which loss of it will entail on him: all joined with a general aversion to acts injurious to others, which arises from the inherited effects of experience. ${ }^{36}$

This seems to accommodate Bellah's vision, and even imply its soldaristic elements, which would follow from the aversion to harming others. But at the same time this is a picture of tradition: that is what Spencer means by 'the inherited effects of experience', which he took to be the product of 'mass of individual inductions [which becomes transformed] into a public and traditional induction impressed on each generation as it grows up'. ${ }^{37}$ 
We seem to be faced with a conundrum. Is Bellah's post-traditional autonomous individual actually different from the liberal autonomous one? Or is the difference this: that Spencer thinks that this individual has morally desirable qualities resulting from experience and from experience congealed into tradition, while Bellah does not? Or is it that Bellah, as his rejection of the 'chaotic' society of southern California from which he came suggests, does not think that people raised under the influence of individualism have these qualities? Or that, unlike southern California, it is 'a society in which he feels like a full participating member, whose goals he shares and can meaningfully contribute to'?

The most plausible answer to this question is that Bellah does not think his subjects live in such a society, but that they secretly crave one, or would be better off if they were in one. But this is no longer a historical question alone: it is a morally freighted normative judgement derived from his Marxist past, which is no longer an empirical claim but a definitional one, in which the definition of such terms as 'meaningfully contribute to' carry the burden of the definition rather than the subjective experience of participation. The same can be said for MacIntyre, and perhaps for Giddens. To point this out is to ask whether the concept of post-traditionalism can be separated from the grand narratives of anti-liberalism and its philosophical anthropology, and from its normative ideals of solidarity and equality.

\section{The normative dimension}

When we trace the history of ideas about modernity, we can see the different normative attitudes toward it through the litmus test of the vision each of them has toward what they take to be the modern self. Spencer embraced it, and did not regard liberalism as an interregnum, as a chaos to be overcome; the post-traditionalists differed. The normative stance we can associate with the idea of post-traditionalism contains elements of Bellah's positive vision of the right kind of modernity. Bellah's model, decoded, is traditional Left modernism, a kind of socialism minus the idea of the public ownership of the means of production. The idea of participation and sharing goals of amelioration do the work that traditional socialist programmatics did. But the focus is now different, and the difference is key to understanding the normative force of the idea of post-traditionalism, one aspect of which is the recognition of the end of ideology and the turn from ideological orthodoxies to ideas of process and participation.

Alasdair MacIntyre, in his early writings, makes a sociological distinction, in terms of what he describes as 'two quite different sets of phenomena, which do as a matter of fact coexist within our society'. 
There are on the one hand the language and the concepts of those people who have continued to live within a tolerably well-established moral framework with a tolerably well-established moral vocabulary. [...] Members of this type of social group possess a list of what they take to be the virtues and vices; moreover they possess a concept of the virtues such that the authority which requires their practice is not conferred by the agent's choice. [...] Indeed choices of moral standards are judged correct or incorrect in the light of their understanding of the virtues and vices. ${ }^{38}$

On the other hand,

There are ... individuals who have a different kind of moral vocabulary. They do not belong to a single homogeneous moral community with a shared language and shared concepts. Instead they find themselves solicited from different standpoints. They cannot avoid choice, and what moral standards they adopt depends upon their own choices. So choice is the fundamental moral concept and there are no objective impersonal standards in the light of which ultimate choices can be criticized. ${ }^{39}$

MacIntyre is decidedly hostile to the latter type, which looks like the reflexive self of Giddens, and comments that ' $[t]$ he greatest contemporary moral achievement is the creation of the type of community where shared ends and needs make possible the growth of a common life and a common commitment, which can be expressed in a common language'. ${ }^{40}$

The fact that there is no such moral achievement on the horizon is, so to speak, the post-traditional condition: in this respect the three are in agreement. The distance between this vision and Bellah's at this point is small: perhaps it is no more than the space marked by the 'relatively' that appears in Bellah's account, which tries to preserve the modern autonomous self in a new moral community. ${ }^{41}$ But MacIntyre's version introduces an element that threatens the possibility of any such community: individuals who are autonomous are forced to choose between 'standpoints' which provide them with moral standards, but these are standards that conflict with the standards of others. And this points to a crucial feature of the present: the problem of the actual existence of different moral standpoints, mostly deriving from 'traditional' subcultures, co-existing within the same community, and faced with the problem of accommodating one another.

This gives us a new problem: multiculturalism. But we are thrown back to the old trilemma. Either we accept something like a liberal framework, of shared rules but few shared ends, and treat individuals as autonomous bearers of culture who get along with one another under these rules, or we can hope for spiritual regeneration that overcomes difference, or we can seek new values that allow for a positive relation between cultures. 
Giddens formulates this problematic most clearly, as a normative, or one might say 'performative', idea. Tradition once supplied a basis for community, but it was a rigid and oppressive basis that 'crushed individual autonomy'. ${ }^{42}$ It was also based on exclusion and 'traditions of family and gender ${ }^{43}$ that are themselves oppressive. The existence of a variety of cultures in modern societies makes a return to this kind of community impossible. What is needed is something different, and cosmopolitan in character, meaning accepting of the existence of this variety and seeking a peaceful way of accommodating it. But to appeal to cosmopolitanism as a solution is to concede that non-cosmopolitanism, meaning mutual intolerance between traditions, is the problem. This is thus a somewhat paradoxical argument: it concedes the persistence of traditions in the different cultural communities, without which there would be no multiplicity of cultures. Tradition, for Giddens, is thus normatively bad - oppressive - but still powerful and in need of more than mere accommodation, namely to be recognized and accepted by others as good.

Giddens' performative solution to the problem of mutually intolerant traditions is 'Active Trust', leading to a 'positive spiral' of trust-building that creates a functional substitute for 'traditional' community and which builds obligation at the level of personal relations based on 'the communication of difference, geared to an appreciation of integrity'. ${ }^{44}$ The process involved is presented as tradition-free: 'integrity' is something that does not require, or seems not to require, adherence to particular traditions. It transcends difference and can be recognized in spite of difference. But it can be understood in terms of the fulfilment of reciprocities such that 'the other is someone on whom one can rely, that reliance becoming a mutual obligation'. This is obligation without tradition, which 'will stabilize relationships in so far as the condition of mutual integrity is met' ${ }^{45}$ It is also, ironically, an echo of Spencer's own vision of society free from religion and based on trust between free contract makers.

Giddens, however, cites a different source: John Dewey's notion of 'liberalism'. Dewey claims that a democratic order requires a 'socially generous' attitude, and the 'capacity to share in a give and take experience'. ${ }^{46}$ Dewey supposed, and Giddens perhaps assumes, that this would lead to new forms of collective action. In the 1930s this was going to be 'planning'. For Giddens, however, politics itself requires something different: 'Civil Association', which respects the autonomy of others and amounts to people living in an 'intelligent relationship' with one another governed by rules. This is straightforwardly a liberal concept: it comes directly from Michael Oakeshott ${ }^{47}$ as is clear from Giddens' reference to its opposite, an enterprise association. But Giddens, like Bellah, tries to soften this kind of liberalism with something more solidaristic. So Giddens recommends what he calls 
dialogical democracy, which would not depend merely on active trust of the sort relevant for personal relations - Spencer's solution of contractmaking individuals coming to trust one another - but on a 'cosmopolitan engagement with groups, ideas, and contexts other than one's own even where these engagements have nothing directly to do with the domain of the state'. ${ }^{48}$

This kind of dialogic relationship is possible precisely because of the feature that Giddens believes distinguishes post-traditionalism from mere modernity: reflexivity. And this notion allows him to avoid some obvious problems with his account of tradition. The first problem is that it seems to presume the existence of groups, ideas and contexts that are closely related and continuous over time - which is to say something very close to what was always meant by 'tradition'. Giddens concedes that 'combined with the inertia of habit, this means that, even in the most modernized of modern societies, tradition continues to play a role', though he goes on to insist that 'this role is generally much less significant than is supposed by authors who focus attention upon the integration of tradition and modernity in the contemporary world. ${ }^{49}$

'Much less significant' is a quantitative distinction. But Giddens goes beyond this. He argues that not only is tradition less significant, but also that the 'tradition' that remains is fundamentally different from the tradition of the past. This is, apparently, the difference that warrants the 'post' in 'post-traditional': the discontinuity marked by the notion of post-tradition is not simply a matter of the end of traditions, but is among other things a discontinuity within the category of tradition itself. This denial of the continued significance of tradition, however, is somewhat hollow. There would be no point to dialogue, engagement, and the creation of novel forms of personal relationship based on reciprocity with the 'other' unless there was an 'other' who was, at the same time, governed in some significant way by a different tradition.

This internal discontinuity is the result of the discontinuity which he identifies as is 'reflexivity.' Reflexivity is the distinctive characteristic of modern life. 'The reflexivity of modern social life consists in the fact that social practices are constantly examined and reformed in the light of incoming information about those very practices, thus constitutively altering their character. ${ }^{50}$ This means that the apparent continued role of tradition, which he acknowledges, is an illusion. If tradition is justified reflexively it is no longer tradition: 'For justified tradition is tradition in sham clothing and receives its identity only from the reflexivity of the modern. ${ }^{51}$

This way of making the distinction between mere modernity, in which social practices are questioned, and post-traditionalism, in which the self is created reflexively, creates a muddle. Traditions persist in fact, and 
need respect at least to enable dialogue between the adherents of different traditions. The existence of 'difference' which is a result of these persistent traditions and their communalization is at least part of what forces individuals into reflexivity and choice. A part, perhaps a large part, of the 'incoming information' about our social practices comes from the encounter with other traditions: this was already a feature of 'modernity'. The fact that one must choose itself marks a fundamental break with tradition. One cannot, for example, wear the head scarf as a continuation of traditional practice. Traditional practice was not a choice. To wear it today is to choose based on reflection on the practice of veiling: choosing to affirm one's identity in this way is a paradigmatic act of a post-traditional, reflexive, act of self-creation. This kind of radical individualism is thus no longer merely an option: we are condemned to it. But weren't we condemned to it already by 'modernity'? Isn't the justification of practices, which is supposed to fundamentally change the nature of the traditions that we continue to accept, precisely the constitutive 'altering' that produces, by definition, the reflexive self?

\section{Post-traditionalism defined}

It may be observed that this argumentative strategy makes the category of post-traditionalism immune to refutation by factual observations about the persistence and ubiquity of tradition: the general fact of reflexivity has turned all traditions into post-traditions by definition. But this shifts the explanatory burden, the problem of what is novel about post-traditionalism, to reflexivity. Where does it come from? And this points to a general problem with these distinctions: if it is its own discontinuity, it needs its own explanation; if it is the outcome of something that is already present, it is not a genuine discontinuity. So the argumentative strategy behind the claim of the discontinuous character of post-traditionalism has to exclude arguments that point to continuities. And it has another burden: the discontinuity cannot be the same as the discontinuity that produced 'modernity'. If it is, 'the post-traditional', as a category, collapses into the familiar category of 'the modern'.

Bellah's original point about the character of post-traditional of religion was this: there were once religious frameworks monopolized by religious groups, orthodoxies, but these have now become open to question. He formulates this in terms of the self, and ends with an appeal to something akin to reflexivity:

Not only has any obligation of doctrinal orthodoxy been abandoned by the leading edge of modern culture, but every fixed position has become open to 
question in the process of making sense out of man and his situation. This involves a profounder commitment to the process I have been calling religious symbolization than ever before. The historic religions discovered the self; the early modern religion found a doctrinal basis on which to accept the self in all its empirical ambiguity; modern religion is beginning to understand the laws of the self's own existence and so to help man take responsibility for his own fate. ${ }^{52}$

Taking responsibility for one's own fate rather than ascribing it to God and meekly accepting the demands of tradition is the product, for Bellah, of religious development, beginning with the 'discovery' of the self by the historic religions: so for him this is the past element that leads to reflexivity. But reflexivity is not enough as a basis for social life. Indeed, one might say it is merely corrosive of social life, because there must be some non-reflexive, taken for granted, basis for social relations.

With this we come to a conflict between reflexivity and solidarity. The 'type of community where shared ends and needs make possible the growth of a common life and a common commitment, which can be expressed in a common language', ${ }^{53}$ which we have seen is MacIntyre's preferred but unobtainable version of the solidaristic values option, is precisely the type of community that liberalism, which accommodates different ends and needs without a 'common life and a common commitment', cannot create. From the point of view of this kind of community, liberalism is simply an arrangement, a compromise in a society without common commitments. MacIntyre makes this point relentlessly, when he argues that the existence of moral pluralism, in contemporary society, and in English society in the nineteenth century, meant that there was no such common base.

MacIntyre makes another point, which bears directly on the problem of the need for a non-reflexive basis for social life. He said that the very lack of a common project meant that society elevated and depended on what he called 'the secondary virtues of co-operation, of compromise, of a pragmatic approach, of fairness'. ${ }^{4}$ The idea of civil association to which Giddens appeals has precisely this character: it is not and cannot be, given the lack of consensus on the religious foundations of the legal and political order, grounded in anything but a kind of compromise. It is essentially about the rules of the game - purposes and goals are individual, and pursued within the framework of the rules, and it is to the rules that citizens must subscribe. It contrasts vividly to the kind of association with shared collective goals: Oakeshott's 'enterprise association'. 55

Was Spencer right to think that there can be a tradition-free society based on trust between autonomous individuals? Is it a kind of default, as MacIntyre pictures it, based on secondary, and presumably non-traditional virtues, which we fall back on when traditions fail to reproduce themselves? 
Is Giddens right to think that there can be a trust-building dialogic relation between the adherents to different contemporary (and reflexive) traditions? Or is the idea of such a dialogue, with its particular notions of generosity, amelioration, participation and so forth, itself an ideology or framework that needs propagation and acceptance? Put even more simply, is cosmopolitan liberalism itself a tradition? There is another question lurking behind this: are there in fact societies that approximate this ideal? What do they look like? Are they post-traditional in the sense of 'tradition-free'? Or does this kind of cooperation itself depend on traditions, on a moral framework or set of values of some sort? And could it be that this is the kind of society we already inhabit, based on a long-standing liberal cosmopolitan tradition of accommodating other cultures?

\section{The idea of rupture}

Post-traditionalism as a concept depends on the idea of rupture. But our sense of rupture as well as our sense of continuity is subject to an important illusion. The illusion can be illustrated by Robert Putnam's Bowling Alone, ${ }^{56}$ which purported to show the decline in associational activities in the United States. Necessarily, this was concerned with associational activities popular in the past, and their decline, such as the bowling leagues referred to in the title. What it could not address, or did not address, was the development of novel forms of association, or forms of association that have not been recognized as such. It is evident that internet-based forms of association have increased, radically, and that phenomena such as women's book clubs have become more important. If we do not take our eyes from the historical rear-view mirror, we are doomed to always seeing traditions recede.

An example of this is the concept of honour. On the one hand it is a relic of the past: honour is relative to rank, and belongs to a society of ranks of the kind that Europe abolished and America never had. It was governed by such sanctions as duelling, which has declined of late. When we encounter the forms of honour in other cultures they are alien and non-modern, such as honour killings. In the nineteenth century honour had a large role in German law, ${ }^{57}$ and although the term is alien to Anglo-American law, there is a law of defamation that does something similar. So - did honour simply go away? Or did some of the external forms disappear? Did it persist as one of the elements that enabled capitalism to survive? Or did it survive, even strengthen, as a part of the actual tradition but under different names and guises?

A recent event can put this into focus. A small Toronto Airport posted an advertisement that read 'You're Precious Cargo, not Cattle'. ${ }^{58}$ An 
animal rights activist protested, calling it insulting to cows. The ad was removed. The implication was clear: cows have honour claims, can be dishonoured, and others will defend their honour. We can see this in historical context. Honour became democratized. There was, as a result of changed attitudes toward animals, such as the idea of animal rights, an extension of the democratization of honour to cows. And one can find many other examples of novel applications of honour-like notions, social movements demanding honour, under other names, as well as theoretical claims that validate honour considerations, also under other names, such as in the writings of Axel Honneth on 'recognition'. ${ }^{59}$ But might one instead claim, as Peter Berger did, that there was a new concept, dignity, whose 'discovery took place amid the debunked conceptions of honour', ${ }^{60}$ and therefore a break in tradition. ${ }^{61}$ These are characteristic problems, with no solutions.

Post-traditionalism as a concept depends on the possibly illusory sense that something fundamental has changed. The idea of tradition implies something mental, and the transitions in question, from traditional to modern and then to post-traditional, are mental transitions. But there is typically an ambiguity about cause which undermines the idea of transition: it is not clear whether the external circumstances changed and permitted people to act in accordance with their pre-existing desires, as Bellah suggests was the case with traditional societies, or the desires themselves changed, as new possibilities of objects of desire emerged. And there is another possibility: that the 'tradition' in question was never as rigid as the theory of 'tradition' represented it, and simply changed in the normal way that traditions change, through adaptation and extension to new circumstances. Giddens' idea of reflexivity is a case in point. Did people suddenly become aware in the 1960s that they had practices that they could reflect on, and were therefore forced to either choose to abandon them or to embrace them, in both cases being forced to reflect and choose? Or is this a completely normal and continuous part of social life, and always has been?

In the face of all this indeterminacy, the concept of post-traditionalism must be said to be appealing for other reasons than its cognitive power. The appeal, perhaps, is to be found in its performative implications. We can distinguish two, one discussed by these thinkers, the other found, so to speak, in the streets. The first is exemplified by Giddens' conclusion, to call for dialogue and respect. This is less 'post' than it appears. Dialogue is the fetish of the tradition of liberalism. ${ }^{62}$ And the idea that we progress through dialogue fits with a suppressed and unacknowledged grand narrative to the effect that the various traditions of the world are mixtures of moral truth and error, and that somehow the interaction of these traditions will bring about a purified, universal, 'rational good', in the phrase 
of Hobhouse - the last Spencerian, in many ways. Dialogue then becomes the performative act commanded by the goal of progress, with cosmopolitanism is its apex. ${ }^{63}$ It echoes Spencer himself, who envisioned a future in which religious authoritarianism would lose its grip, and people would come to relate to one another as agents able to freely contract with one another and therefore to develop the trusting relations appropriate to the relation of contract. The performative side of post-traditionalism offers this, but also less, because it contemplates - or embraces - the possibility that there can be no progress beyond minimal multi-cultural trust. If this is the case, tradition has disappeared by definition, not in its role in people's lives.

\section{Notes}

1 Robert Bellah, Beyond Belief: Essays on Religion in a Post-Traditionalist World (Berkeley, CA: University of California Press ([1970] 1991).

2 Herbert Spencer, The Principles of Ethics, vol. 1 (New York: D. Appleton and Company, 1895), pp. 477-554.

3 Herbert Spencer, The Man versus the State: Containing 'The New Toryism', 'The Coming Slavery', 'The Sins of Legislators' and 'The Great Political Superstition' (London: Williams and Norgate, 1885), pp. 800-1.

4 Stephen Turner, 'Religion and British Sociology: The Power and Necessity of the Spiritual; Sociology in Britain', in John Holmwood and J. Scott (eds), The Palgrave Handbook of Sociology in Britain (London: Palgrave, 2014), pp. $97-122$.

5 Arthur J. Balfour, The Religion of Humanity: An Address Delivered at the Church Congress, Manchester, October 1888 (Edinburgh: David Douglas, 1888).

6 Theodore M. Porter, Karl Pearson: The Scientific Life in a Statistical Age (Princeton, NJ: Princeton University Press, 2004), p. 90.

7 Karl Pearson, The Ethic of Freethought (London: T. Fisher Unwin, 1888), p. 20.

8 E. A. Burroughs, Bishop of Ripon, 'Is Scientific Advance Impeding Human Welfare?', Literary Digest, 95 (1927), 32.

9 Bertrand Russell, Marriage and Morals (New York: W. W. Norton and Co., [1929] 1957).

10 Christopher Dawson, Christianity and Sex (London: Faber \& Faber, 1930), esp. pp. 13-16.

11 Benjamin Barr Lindsey and Evans Wainwright, The Companionate Marriage (New York: Boni \& Liveright, 1927).

12 Charles Ellwood, The Reconstruction of Religion: A Sociological View (New York: Macmillan, 1922).

13 Reinhold Niebuhr, Moral Man and Immoral Society (New York: Charles Scribner's Sons, 1932). 
14 R. H. Tawney, The Acquisitive Society (New York: Harcourt, Brace and Howe, 1920); Religion and the Rise of Capitalism (New York: Harcourt, Brace \& Company, 1926); Equality (London: George Allen \& Unwin, 1931).

15 John Dewey, 'Challenge to Liberal Thought', Fortune, 30 (1944), 155-7, 180-90. Robert Maynard Hutchins, 'Toward a Durable Society', Fortune, 27 (1945), 159-60, 194-207.

16 Keith Clements (ed.), The Moot Papers: Faith, Freedom and Society 1938-1944 (London: Bloomsbury, 2009).

17 T. S. Eliot, Christianity and Culture (New York: Harcourt Brace, [1939] 1976).

18 Alan Jacobs, The Year of Our Lord 1943: Christian Humanism in an Age of Crisis (Oxford: Oxford University Press, 2018).

19 J. P. Mayer, 'Reflections on Equality', in Leszek Kolakowski and Stuart Hampshire (eds), The Socialist Idea: A Reappraisal (New York: Basic Book, 1974), pp. 59-73.

20 Karl Mannheim, Man and Society in an Age of Reconstruction, trans. Edward Shils (New York: Harcourt, Brace and Company, [1929] 1940); 'The Crisis in Value' in Diagnosis of Our Time: Wartime Essays of a Sociologist (Abingdon, Oxfordshire: Psychology Press [1943] 1997), pp. 12-30; Freedom, Power, and Democratic Planning (Oxford: Oxford University Press, 1950); S. Turner and R. Factor, Max Weber and the Dispute Over Reason and Value: A Study in Philosophy, Ethics, and Politics (London: Routledge \& Kegan Paul, Ltd., 1984), pp. 154-6.

21 Plamena Panayotova (ed.), The History of Sociology in Britain: New Research and Revaluation (London: Palgrave Macmillan, 2019).

22 Richard Hofstader, The American Political Tradition and the Men Who Made It (New York: A. A. Knopf, 1948).

23 Robert N. Bellah, 'McCarthyism at Harvard', New York Review of Books (10 February 2005), www.nybooks.com/articles/2005/02/10/mccarthyism-atharvard/ (accessed 2 January 2020).

24 Paul Blackledge and Neil Davidson (eds), Alasdair MacIntyre's Engagement with Marxism: Selected Writings 1953-1974 (Chicago, IL: Haymarket Books, 2005), p. 52.

25 Giovanna Borradori, The American Philosopher: Conversations with Quine, Davidson, Putnam, Nozick, Danto, Rorty, Cavell, MacIntyre, Kubn (Chicago, IL: University of Chicago Press, 1994), pp. $254 \mathrm{ff}$.

26 Robert N. Bellah, 'Introduction', in Bellah and Tipton (eds), The Robert Bellah Reader (Durham, NC: Duke University Press, 2006), p. 2.

27 Ulrich Beck, Anthony Giddens and Scott Lash, Reflexive Modernization: Politics, Tradition and Aesthetics in the Modern Social Order (Palo Alto, CA: Stanford University Press, 1994).

28 Anthony Giddens, The Consequences of Modernity (Stanford, CA: Stanford University Press, 1990), p. 1.

29 Ibid., p. 3.

30 Ibid., p. 6. 
31 Anthony Giddens, Modernity and Self-Identity: Self and Society in the Late Modern Age (Stanford, CA: Stanford University Press, 1991), p. 107.

32 Bellah, Beyond Belief, p. 42.

33 Ibid., pp. 158-9.

34 Ibid.

35 Robert Bellah et al., Habits of the Heart: Individualism and Commitment in American Life (Berkeley, CA: University of California Press, 1985).

36 Herbert Spencer, The Data of Ethics (New York: A. L. Burt Company, 1879), p. 127.

37 Ibid., pp. 135-6.

38 Alasdair MacIntyre, Secularization and Moral Change (New York: Oxford University Press, 1967), p. 51.

39 Ibid., p. 14.

40 Ibid., p. 57.

41 Interestingly, Bellah and MacIntyre later connected. Their relation is discussed in Garrett Potts, 'From Meaningful Work to Good Work: Re-examining the Moral Foundation of the Calling Orientation' (PhD dissertation, Department of Philosophy, University of South Florida, 2019).

42 Anthony Giddens, 'Post-Traditional Civil Society and the Radical Center', New Perspectives Quarterly, 15:2 (1998), 16.

43 Ibid.

44 Ibid.

45 Ibid.

46 Ibid., 17.

47 Michael Oakeshott, On Human Conduct (Oxford: Clarendon Press, [1975] 1991), p. 112.

48 Giddens, 'Post-Traditional Civil Society', 17.

49 Giddens, Consequences of Modernity, p. 38. The reference might be to, among others, Edward Shils, for whom this was a theme. See esp. Lenore T. Ealy, 'The Recovery of Tradition', in Christopher Adair and Stephen Turner (eds), The Calling of Social Thought: Rediscovering the Work of Edward Shils (Manchester: Manchester University Press, 2019), pp. 61-78.

50 Giddens, Consequences of Modernity, p. 38.

51 Ibid.

52 Bellah, Beyond Belief, p. 42.

53 MacIntyre, Secularization and Moral Change, p. 57.

54 Ibid., p. 49.

55 Oakeshott, On Human Conduct.

56 Robert Putnam, Bowling Alone: The Collapse and Revival of American Community (New York: Simon and Schuster, 2000).

57 Ann Goldberg, Honor, Politics, and the Law in Imperial Germany, 1871-1914 (Cambridge: Cambridge University Press, 2010).

58 Canadian Press, 'Island airport grounds ad 'insulting' to cows', Toronto Sun, 30 June 2017, www.torontosun.com/2017/06/30/island-airport-grounds-adinsulting-to-cows (accessed 21 August 2019). 
59 Axel Honneth, 'Grounding Recognition: A Rejoinder to Critical Questions', Inquiry, 45:4 (2002), 499-519.

60 Peter Berger, 'On the Obsolescence of the Concept of Honor', in Stanley Hauerwas and Alasdair MacIntyre (eds), Revisions: Changing Perspectives in Moral Philosophy (Notre Dame, IN: Notre Dame University Press, 1983), p. 176.

61 Needless to say, a concept like dignity is not 'discovered': dignitas was an important Roman concept with legal implications which came to be precisely calibrated to an elaborate system of ranks in Roman society. See Max Radin, 'Roman Concepts of Quality', Political Science Quarterly, 38 (1923), 262-89. It is just another term in the honour family of concepts; see Remy Debes (ed.), Dignity: A History (New York: Oxford University Press, 2017). What was novel, for these writers, was its egalitarian extension. Berger's argument that the discovery of dignity arose because honour was debunked is simply circular: honour, as he understands the concept, can't be found in societies without ranked social roles because for him honour means honour for ranked social roles.

62 Tartly dismissed recently by Raymond Guess, 'A Republic of Discussion: Habermas at Ninety', The Point (18 June 2019), https:/thepointmag.com/2019/ politics/republic-of-discussion-habermas-at-ninety (accessed 11 September 2020).

63 I leave aside the point made by Martha Nussbaum that cosmopolitanism is itself a tradition, reaching back to the ancient world, which is itself in trouble. Martha Nussbaum, The Cosmopolitan Tradition: A Noble but Flawed Ideal (Cambridge, MA: Harvard University Press, 2019). 